\title{
Prevalence of Pulmonary Mycotic Lesions and Antifungal Susceptibility Pattern of Fungi Isolated from Nigerian Trade Cattle
}

\author{
Anthony Christian Mgbeahuruike*, Amarachukwu Agoha, Iniobong Chukwuebuka Ikenna \\ Ugochukwu, Wilfred Ezema and Remigius Ibe Onoja
}

Department of Veterinary Pathology and Microbiology, Faculty of Veterinary Medicine, University of Nigeria, Nsukka, Nigeria

*Corresponding author: Anthony.mgbeahuruike@unn.edu.ng

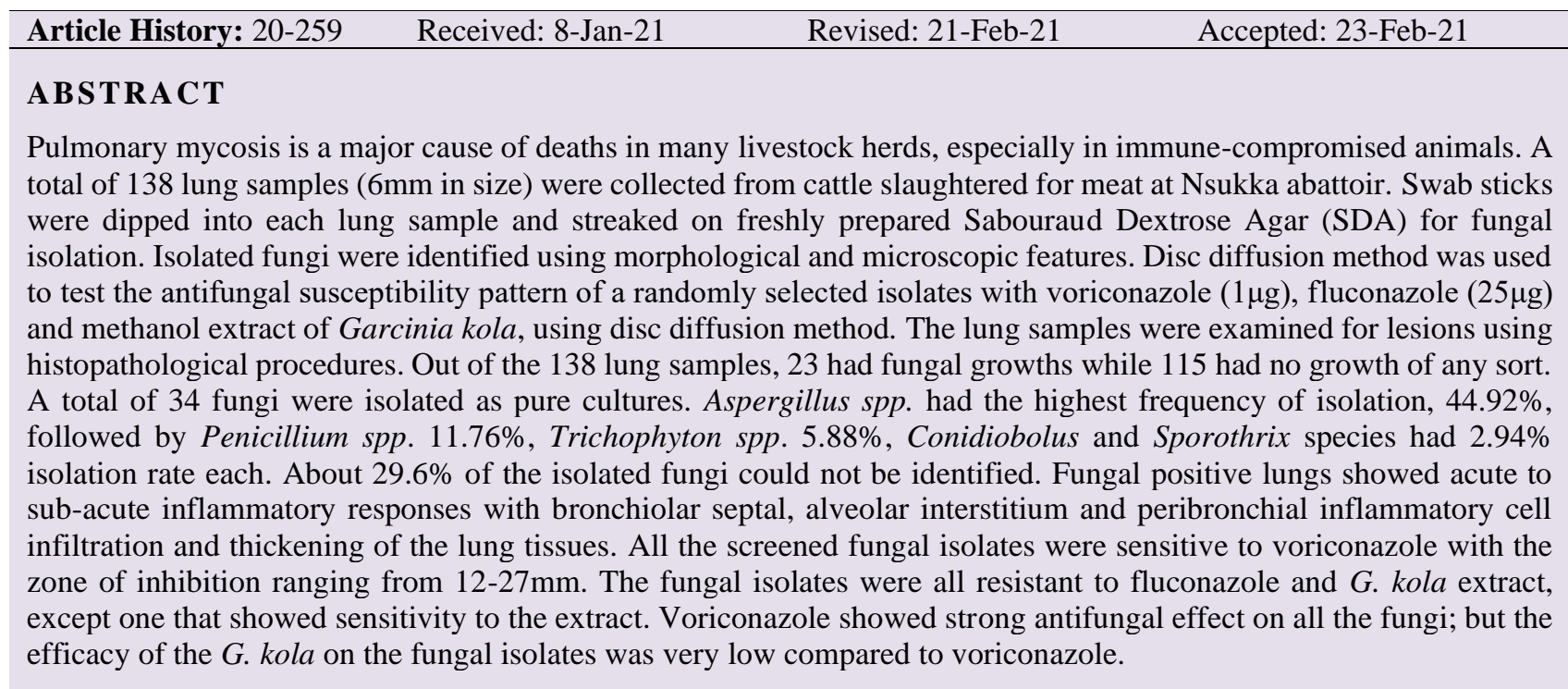

Key words: Fungi, Fluconazole, Cattle, Lesions, Mycosis, Pulmonary, Voriconazole.

C202I IJVS - All Rights Reserved

\section{INTRODUCTION}

In recent times, the livestock industry has experienced a huge rise in development. Due to the demand for meat and other livestock products, the sector has contributed to annual revenue of $\$ 1.4$ trillion in most developing countries. The livestock industry is a major source of employment generation in many countries, and it is also a source of livelihood to over 600 million people at a global level (Thornton et al. 2006; Thornton 2010).

In Nigeria, there are over 15.3 million cattle comprising of different breeds (Kubkomawa 2017; Ovharhe et al. 2020). Some of the popular breeds indigenous to Nigeria include Sokoto Gudali, Muturu, Adamawa Gudali, Wadara, Azawak, Keteku, White Fulani, Red Bororo, Ndama and Kuri (Babayemi et al. 2014; Kubkomawa 2017). Cattle provides animal proteins, beef, milk, hides and skin for many households, in most cases, they are used for traction in some parts of the Nigeria (Kubkomawa 2017). However, cattle production in Nigeria is faced with challenges such as diseases, inadequate nutrition, lack of improved breeds, poor marketing strategies, structural problems, and social factors (Yesuf et al. 2012).

Pulmonary mycoses are important from public health and economic point of view as they lead to high mortality especially in immune-compromised animals and can be of great zoonotic importance. Although mycotic pneumonia is rare in cattle, it can be caused by Coccidioides immitis, Aspergillus species and other opportunistic fungal pathogens (Panciera and Confer 2010). In cattle, mycotic pneumonia has been associated with lesions such as epithelial metaplasia of the airways, bronchitis, bronchiectasis, interstitial fibroplasia, as well as bronchiolitis obliterans (Ramírez-Romero et al. 2012). The importance of fungal infections in both humans and

Cite This Article as: Mgbeahuruike AC, Agoha A, Ugochukwu ICI, Ezema W and Onoja RI, 2021. Prevalence of pulmonary mycotic lesions and antifungal susceptibility pattern of fungi isolated from Nigerian trade Cattle. International Journal of Veterinary Science 10(4): 294-300. https://doi.org/10.47278/journal.ijvs/2021.054 
Int J Vet Sci, 2021, 10(4): 294-300.

animals have been emphasized in some studies due to the rising interest in the diseases caused by fungi (Seyedmousavi et al. 2018). In healthy animals with intact immunity, fungi rarely cause diseases, however, opportunistic fungal pathogens can cause infections in immunocompromised animals (Seyedmousavi et al. 2018; Imran et al. 2020). Despite improvements in therapeutic options and new diagnostic tools, fungal infections are major cause of mortalities observed in cattle (AlastrueyIzquierdo et al. 2015). Therefore, it is important to initiate the correct antifungal therapy for a better treatment outcome (Patel et al. 2009). However, the problem of fungal resistance to the available antifungal drugs is a huge challenge to treatment of fungal diseases. This situation has been attributed to indiscriminate use of antifungal agents, coupled with the increase in opportunistic fungal infections. Resistance to antifungal therapy can occur due to clinical or microbiological dynamics. When a fungal infection is treated with the optimal dosage of the appropriate antifungal drug and the infection persists, then the infection is said to be clinically resistant to the therapeutic agent (Sanglard 2011). Careless use of antimicrobials has resulted in microbial resistance with high level of morbidity and mortality in animals (McEwen and Fedorka-Cray 2002; Feifei et al. 2020). Various cases of antimicrobial resistance reported in humans have been traced to resistant microbes that are thought to have originated from livestock (Paphitou 2013; Mamun et al. 2017). As one of the strategies to stem this rising challenge, efforts are being made to tap into medicinal plants as the alternative to the conventional antimicrobial agents.

Garcinia kola (bitter kola) is a medicinal plant with high economic value, and it is commonly found in countries in West Africa. The medicinal value of the plant has been found to reside in the seeds, nuts, fruits, and bark; and each part has been demonstrated to be effective in the treatment of diseases (Okoli 1991). Dimeric flavonoid molecules fused together with biflavonoid, xanthones and benzophenones have been shown to constitute the bioactive constituents of the plant (Seanego and Ndip 2012). G. kola is eaten in most homes in suspected cases of consumption of bacteria-contaminated food, an indication that the plant has antibacterial property (Icheku et al. 2018). The antimicrobial, anti-inflammatory, antiviral, antidiabetic, and antioxidant properties of $G$. kola is thought to be due the phenolic compounds present in the plant (Oluyemi et al. 2007; Emily et al. 2020). The alcoholic extract of $G$. kola has been reported to show inhibitory activities against numerous fungi and bacteria (Ezeifeka et al. 2003). The antifungal activity of $G$. kola has been attributed to the presence of hydroxybiflavonoids (Seanego and Ndip 2012). Exploring the antimicrobial properties of this plant in the treatment of pulmonary mycosis will help to reduce the burden posed by resistance to the available antifungal agents.

The present study investigated the prevalence of pulmonary myscosis and its attendant lesions in cows slaughtered for meat at Nsukka Abattoir in Enugu State, Nigeria. The study also compared the antifungal pattern of two conventional antifungal agents (fluconazole and voriconazole) with the medicinal plant, G. kola on the isolated fungal agents.

\section{MATERIALS AND METHODS}

\section{Ethical Approval}

This study was approved by the institutional head of the Faculty of Veterinary Medicine University of Nigeria, Nsukka and the findings from the study were reported with strict compliance to the procedures outlined in ARRIVE guidelines for reporting in vivo experiments in animal research (Karp et al. 2015).

\section{Sampling and Data Collection}

A total of 138 lung samples of slaughtered cattle were examined by palpation before collection for fungal and histopathology investigations. Collected samples for mycological investigation were placed in polythene bags, labelled appropriately, and transported in a cooler with ice to the Laboratory for further processing.

\section{Fungal Isolation and Identification}

Smears of each lung sample was streaked evenly on a freshly prepared Sabouraud Dextrose Agar (SDA). The SDA plates were incubated at room temperature $\left(25-30^{\circ} \mathrm{C}\right)$ for 3-4 weeks. Fungal growths were sub-cultured on fresh SDA plates for purification and identification according to Sephavard et al. (2009).

Further identification using microscopic features was done following the methods by Aneke et al. 2018. The fungi were classified into genus and species levels using both morphologic and microscopic features (Ellis et al. 2000; Baron et al. 2003). Each fungal isolate was stocked on fresh SDA for further analysis.

\section{Methanol Extraction of Garcinia kola}

The fresh seeds of $G$. kola were purchased from Ogige market, Nsukka and identified at the Department of Plant Science and Biotechnology, University of Nigeria, Nsukka. The seeds were dried under open air for two weeks and crushed using electric blender. The crushed samples $(50 \mathrm{~g})$ were poured into an extraction chamber (Soxhlet extractor) connected to a $1 \mathrm{~L}$ round-bottom flask and a condenser. The extraction of the active constituents of the plant was done with $300 \mathrm{~mL}$ of methanol added to the Soxhlet extractor. The extraction time was $6 \mathrm{~h}$. A rotary evaporator operated under reduced pressure at $45^{\circ} \mathrm{C}$ was used to evaporate the solvent (methanol) after the extraction of the plant's bioactive component.

\section{Antifungal Activity of the Methanol Extract of Garcinia kola}

The disc diffusion procedure as described by Bauer et al. (1966) was employed for the antifungal susceptibility test. Two antifungal agents; fluconazole $(25 \mu \mathrm{g})$ and voriconazole $(1 \mu \mathrm{g})$ purchased from Oxoid ${ }^{\circledR}$, and G. kola extract $(50 \mu l)$ were used for the antifungal susceptibility test. The assay was done using 3-5 days old cultures of the fungal isolates. About $3 \mathrm{~mm}$ agar plugs of each randomly selected fungus was put a sterile test tube containing $5 \mathrm{ml}$ distilled water. The sample was properly vortexed after hand shaking and allowed to stand at room temperature for $15 \mathrm{~min}$. The supernatant was transferred to a fresh test tube to harvest the fungal spores; this was adjusted to 0.5 McFarland's standards (1.5 x 108 spores per ml) using normal saline (McFarland 1907). The spore preparation was spread gently and evenly on the surface of freshly 
prepared SDA and allowed to dry. Antifungal discs containing fluconazole $(25 \mu \mathrm{g} / \mathrm{ml})$ and voriconazole $(1 \mu \mathrm{g} / \mathrm{ml})$ were placed on the surface of the plates containing the fungal spores. Approximately $50 \mu \mathrm{l}$ of $G$. kola extract was applied into $3 \mathrm{~mm}$ holes bored with sterile borer on each agar plate and the plates were incubated at room temperature for 3-10 days. The zones of inhibition were recorded in millimeters.

\section{Histopathological Analysis}

Lung samples thought to have lesions were fixed in $10 \%$ neutral buffered formalin. The fixed tissues were dehydrated in graded alcohol and stained with hematoxylin and eosin (Bancroft and Gamble 2002). The slides were viewed with light microscope and photomicrographs of the lesions were taken using a Motic Images plus 2.0 digital cameras (Motic China Group Ltd. 1999-2004).

\section{Statistical Analysis}

The data from the fungal assay and identification were analyzed using descriptive statistics and were presented as percentages.

\section{RESULTS}

\section{Fungal Isolation}

One hundred and thirty-eight (138) lung samples were cultured on SDA, but only 23 samples had fungal growths. Thirty-four fungal isolates were obtained after subculturing to get distinct cultures (Fig. 1), some of the lung samples had more than one fungal growth. The pure cultures were matched with pictures of fungal cultures from previous works and were identified further using microscopic structures (Fig. 2). Eight Aspergillus spp. were identified, four Penicillium spp., two Trichophyton spp. one Pythium spp., one Conidiobolus spp., one Sporothrix spp. were also identified. Others could not be identified. The Aspergillus spp. had the highest rate of occurrence $44.92 \%$, followed by Penicillium spp. $11.76 \%$, Trichophyton spp. 5.88\%, Conidiobolus spp., and Sporothrix spp. had $2.94 \%$ rate of occurrence each. The unidentified fungi had $29.41 \%$ rate of occurrence.

\section{Antifungal Sensitivity Test}

The fungal isolates were screened with two antifungal agents (Voriconazole and Fluconazole) and a methanol extract from $G$. kola to ascertain their antifungal susceptibility patterns. Voriconazole had the highest activity against the fungal organisms, followed by the $G$. kola extract (Table 1). Fluconazole had no activity as the organisms were resistant to the drug. All the fungal isolates screened for antifungal susceptibility were sensitive to voriconazole, with the zone of inhibition ranging from 12$27 \mathrm{~mm}$ (Table 1). The fungi were all resistant to fluconazole, while only one isolate was sensitive to the $G$. kola methanol extract. All the Aspergillus species screened in this study showed sensitivity to voriconazole but the zone of inhibition of each isolate was variable (Table 1).

\section{Histopathology}

Most of the analyzed tissues showed no observable histopathological lesions. The few sections of fungal positive lungs showed acute to sub-acute inflammatory response (acute necrohemorrhagic lesions) comprising of
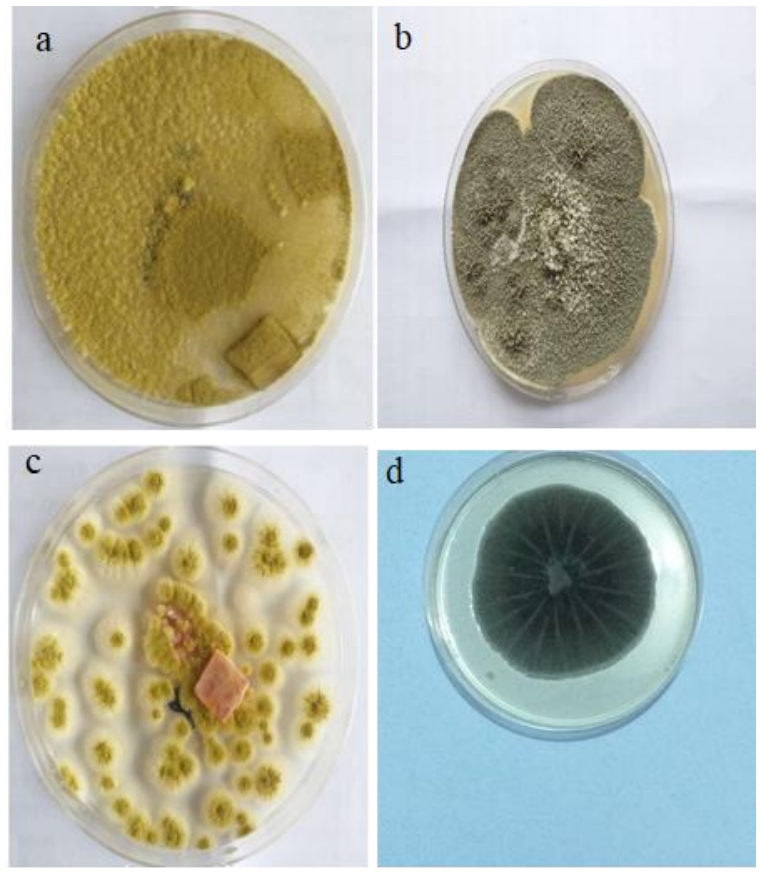

Fig. 1: Morphological presentation of some fungi isolated in this study. Smears of lung sample were cultured in SDA and subcultured in fresh SDA after 1-4 weeks incubation, (a-c) Aspergillus species (d) Unidentified.
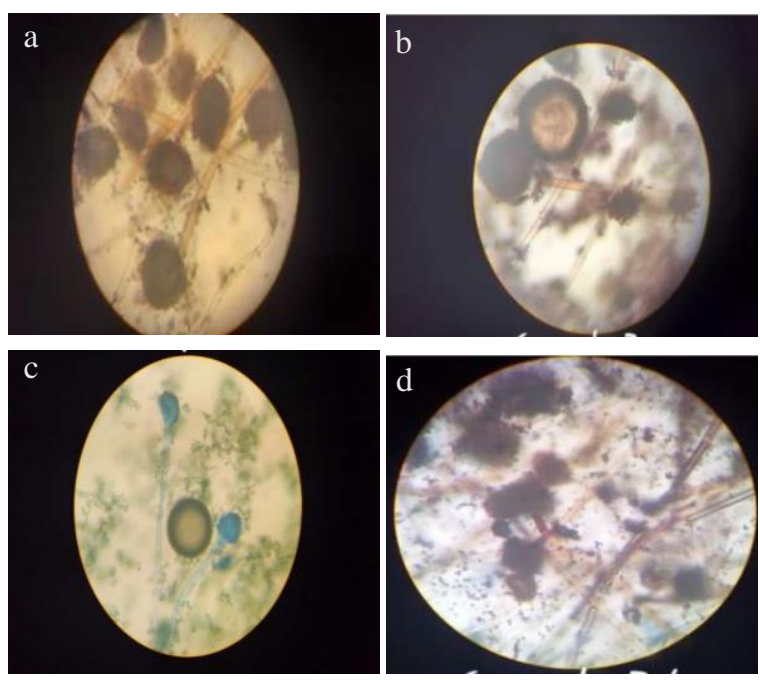

Fig. 2: Microscopic features of a selected fungal species identified in this study. Microscopic examination was done using the lactophenol cotton blue and wet mount methods, (a-d) Aspergillus species.

neutrophils and macrophages with few lymphocytes (Fig. 3). Bronchiolar septal, alveolar interstitium and peribronchial inflammatory cell infiltration and thickening were very prominent (Fig. 4). These were more common in the Aspergillus infected lungs. The lungs with negative fungal growths showed normal lung tissues with typical peribronchial lymphoid cells (Fig. 5).

\section{DISCUSSION}

Although infection of cattle by pathogenic fungi is self-limiting, they are however the cause of most contagious diseases in livestock. Pulmonary mycosis is a common disease of livestock in the tropics and by extension, 
Int J Vet Sci, 2021, 10(4): 294-300.

Table 1: The antifungal susceptibility pattern of randomly selected fungi screened in this study

\begin{tabular}{lccc}
\hline Fungal Isolate & Voriconazole Diameter $(\mathrm{mm})$ & Fluconazole Diameter $(\mathrm{mm})$ & Garcinia kola Extract Diameter $(\mathrm{mm})$ \\
\hline Aspergillus species & 16 & $\mathrm{R}$ & $\mathrm{R}$ \\
Sporothrix schenkii & 21 & $\mathrm{R}$ & $\mathrm{R}$ \\
Conidiobollus species & 21 & $\mathrm{R}$ & $\mathrm{R}$ \\
Aspergillus species & 14 & $\mathrm{R}$ & $\mathrm{R}$ \\
Aspergillus species & 14 & $\mathrm{R}$ & $\mathrm{R}$ \\
Aspergillus species & 25 & $\mathrm{R}$ & $\mathrm{R}$ \\
Aspergillus species & 27 & $\mathrm{R}$ & $\mathrm{R}$ \\
Aspergillus species & 17 & $\mathrm{R}$ & $\mathrm{R}$ \\
Aspergillus species & 22 & $\mathrm{R}$ & $\mathrm{R}$ \\
Aspergillus species & 12 & $\mathrm{R}$ & 14 \\
\hline
\end{tabular}

Fungal spores harvested from 3-5days old culture were evenly spread on freshly prepared SDA. Antifungal discs containing fluconazole $(25 \mu \mathrm{g} / \mathrm{ml})$ and voriconazole $(1 \mu \mathrm{g} / \mathrm{ml})$ were placed on the surface of the inoculated plates, $50 \mu \mathrm{l}$ of Garcinia kola extract was put into $3 \mathrm{~mm}$ hole made with sterile borer on the media and the plates were incubated at room temperature for 3-10 days for measurement of zone of inhibition. $\mathrm{R}=$ resistance. Zone of inhibition measured in millimeter as the diameter of the area where the drugs prevented the growth of the fungi.

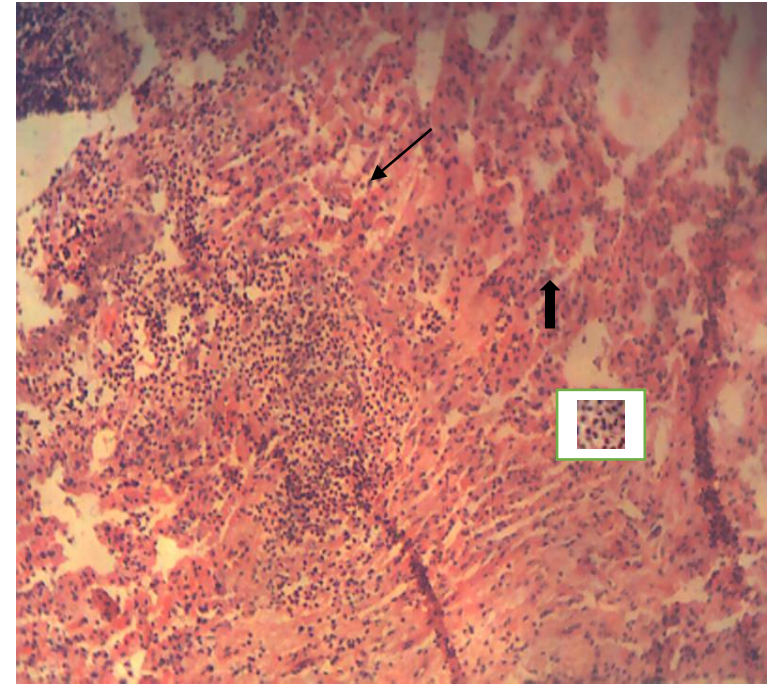

Fig. 3: Photomicrograph of the fungal positive lungs showing alveolo- interstitial hemorrhages, bronchiolar septal, alveolar interstitium and peribronchial inflammatory cell infiltration (Thin arrows) and thickening X10, H\&E. Inset-Inflammatory cells which were mainly Lymphocyes, neutrophils and macrophages.

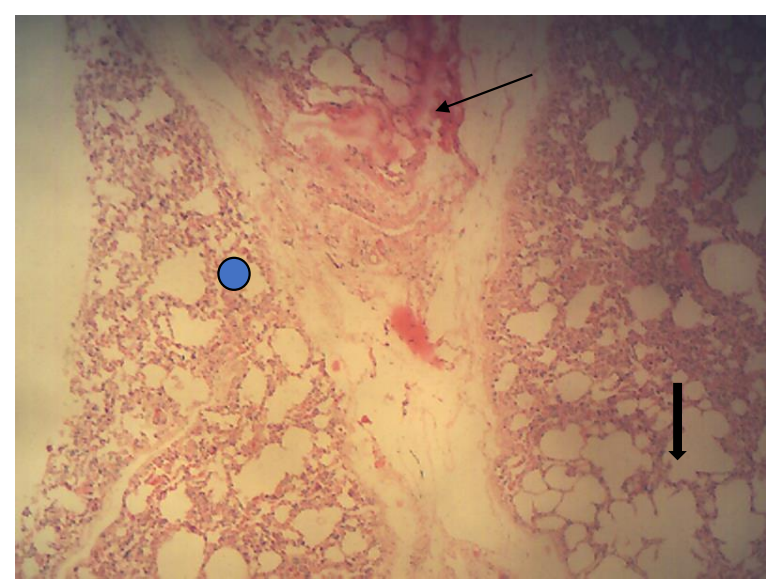

Fig. 4: Photomicrograph of the fungal positive lungs showing interlobular septal oedematous thickening (thin arrows), alveolar interstitium infiltration by inflammatory cell infiltration (A) and Emphysema (Thick arrows) X10 H\&E

a public health issues. In the present study, we investigated the presence of mycotic organisms in the lungs of cattle brought for slaughter in Nsukka Abattoir of Enugu State.

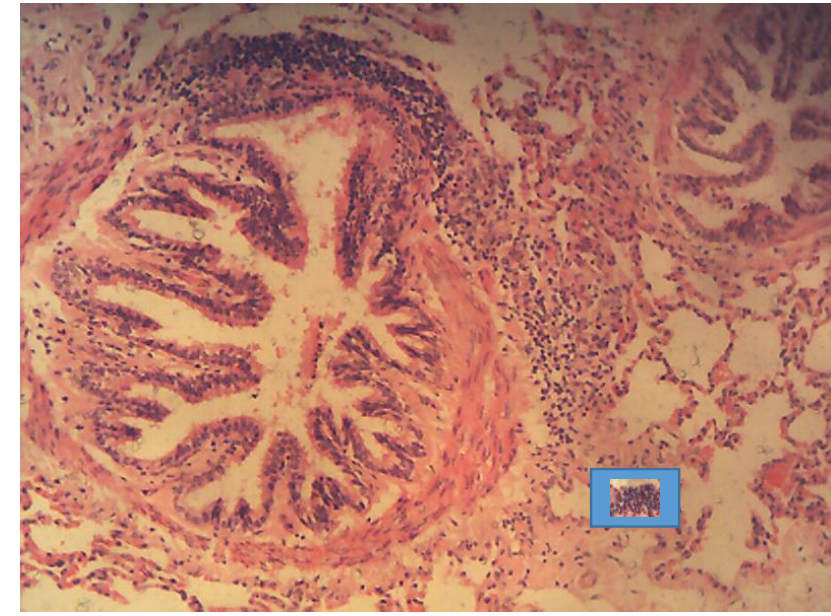

Fig. 5: Photomicrograph of the fungal negative lungs showing normal features with typical peri-bronchial lymphoid cells (arrows). H\&E X40.

We also screened for the antifungal susceptibility pattern of the isolated fungal agents against two conventional antifungal agents and a methanol extract of G. kola. Aspergillus species had the highest rate of occurrence (44.92\%) in all the lung samples screened. Aspergillus species are respiratory pathogens responsible for infection in livestock. The genus Aspergillus causes a mycotic disease known as aspergillosis. Some known species implicated in aspergillosis in animals include Aspergillus fumigatus, A. flavus, A niger, A. terreus, A. glaucus, and A. nidulans. A. fumigatus is a life-threatening opportunistic pathogen (Arne and Deville 2010). The spores of $A$. fumigatus (conidia) if inhaled into the lungs of immunocompromised animals may cause pulmonary aspergillosis. Aspergillosis manifests itself as pulmonary infections in birds (Arne and Deville 2010), mammary gland infections and mycotic abortion in cattle (Puntenney et al. 2003) and guttural pouch mycosis in horses (Dobesova et al. 2012). In a similar study, Chihaya et al. (1991) reported 52.6\% isolation rate of Aspergillus species from the lungs samples of infected cattle. Penicillium, Conidiobolus species and Sporothrix species cause infections in animals and humans, especially when the immune system of the animal is compromised, therefore they could be health risk to the animal handlers (Chan et al. 2013; Schlecht et al. 2015). Penicillium also produces a 
mycotoxin known as ochratoxin which has adverse effects to the liver of most livestock and domestic animals (Seifi et al. 2018).

Sporotrichosis is considered a neglected fungal disease of humans and animals. Animals are exposed to infected plant materials and soil, which can be considered as the source of infection (Rodrigues et al. 2014). S. sckenkii has been found to have many clinical forms such as fixed cutaneous, mucocutaneous, lymphocutaneous, pulmonary, osteoarticular and disseminated forms observed in human beings (Bonifaz and Tirado-Sánchez 2017). However, there has been no literature support for pulmonary infection in cattle where it is known to cause a cutaneous infection. This may be because the disease is more serious in cats than other animal species (Marimon et al. 2007).

Trichophyton spp. had a prevalence rate of $(5.88 \%)$ in the sampled lungs. Their presence in the lungs where no visible clinical signs of pulmonary mycosis were seen may be because this species causes a cutaneous form of mycosis (Dahl 1994). It is also possible that these group of fungi were contaminants in the samples screened in this study, as Trichophyton are mainly dermatophites in most domestic animals. Pythiosis is a granulomatous fungal infection caused by the fungus, Pythium insidiosum. The disease has been reported in dogs, cats, horses, cattle and humans (Pier et al.1994). The low isolation rate of this fungus in this study may be due to environmental factors and the rearing pattern of the animals.

The acute to sub-acute inflammatory response (acute necrohaemorrhagic lesions) and its disseminated localization as observed in the histological section of lungs with positive fungal growth is thought to be associated with the hematogenous route of spread (Jensen et al. 1992). This acute inflammation is an indication of early onset of the fungal agents and the gradual establishment of infection in the lung tissues. The bronchiolar septal, alveolar interstitium, peribronchial inflammatory cell infiltration and thickening observed in the lung tissues did not agree with granulomatous lesions and hyphae seen in previous works by (Jensen et al. 1990). This may be due to the fact that mycotic infections in this present study did not have a chronic course. Similar observation of bronchitis and bronchiectasis were reported by Ramírez-Romero et al. (2012).

The positive fungal lesions were more prominent is all the Aspergillus infected lungs which could be an evidence of pulmonary aspergillosis. Aspergillus infection is a major cause of deaths in immunocompromised animals (Puntenney et al. 2003). Dairy cattle in early lactation and animals in intense antimicrobial therapy are more predisposed to Aspergillus infections (Jensen et al. 1994). However, most of the cattle used in this study were normal or apparently healthy cattle, so it is expected that the observed lesions will be minimal as the animals were not in immune compromised states.

For the antifungal susceptibility test, it was not surprising to see the high activity of voriconazole over the two other antifungal agents. Voriconazole is a broadspectrum antifungal agent, and it is a drug of choice for invasive aspergillosis (Johnson and Kauffman 2003; Cecil and Wenzel 2009; Rosowski et al. 2020). However, cases of strong resistance to voriconazole in invasive aspergillosis caused by $A$. fumigatus species have been reported (Pieter et al. 2019). Voriconazole showed a large protective effect over Amphotericin B in a randomized, multicentre trial (Herbrecht 2002). The G. kola showed very low activity in comparison with voriconazone. In other studies, the diethyl ether extract and the N-hexane extract of $G$. kola showed low antifungal activity against Candida albicans (Ibedu et al. 2018). Furthermore, a comparison between the aqueous and the methanolic extracts of $G$. kola showed that the methanolic extract showed higher antifungal activity (Penduka et al. 2011). This may be because; methanol as an organic solvent, dissolves organic compounds in the G. kola thereby liberating the active ingredients required for antimicrobial activity (Penduka et al. 2011). The antifungal activity of $G$ kola was earlier reported to be due to its hydroxybiflavonoids and quercetin content (Ezeifeka et al., 2003; Seanego and Ndip 2012; Adamu et al. 2020). All the isolated fungal species showed resistance to fluconazole. In separate and independent studies, Candida albicans isolated from the lungs of cattle showed similar resistance to fluconazole (Pfaller et al. 2000). Candida resistance to fluconazole has been linked to the expression of MRR1 gene, which encodes a transcription factor capable of inducing fluconazole (FLZ) resistance in Candida species (Elora et al. 2018). However, all the fungi were sensitive to voriconazole. The Aspergillus species had variable zones of inhibitions on the voriconazole, an indication that each species responded differently to the antifungal agent.

\section{Conclusion}

In conclusion, different fungal species were isolated from the lungs of the screened cattle with Aspergillus being the most prevalent fungi in the sampled lungs. Voriconazole had a more efficacious effect than fluconazole but the efficacy of the $G$. kola on the fungal isolates was too low.

\section{Author's Contribution}

ACM conceptualized the study, designed it, supervised it and drafted the manuscript. AA did part of the laboratory work. ICU helped in the manuscript preparation. WE did the histopatholgical analysis. OIR helped with the histopathological work and also in the manuscript preparation.

\section{REFERENCES}

Adamu A, Ingbian IN, Okhale SE and Egharevba HO, 2020. Quantification of some phenolics acids and flavonoids in Cola nitida, Garcinia kola and Buchholzia coriacea using high performance liquid chromatography-diode array detection (HPLC-DAD). Journal of Medicinal Plants Research 14: 81-87. https://doi.org/10.5897/JMPR2019.6850

Alastruey-Izquierdo A, Melhem MSC, Bonfietti LX and Rodriguez-Tudela JL, 2015. Susceptibility test for fungi: clinical and laboratorial correlations in medical mycology. Revista do Instituto de Medicina Tropical de São Paulo 19: 57-64. https://doi.org/10.1590/S0036-46652015000700011

Aneke CI, Ugochukwu ICI, Okafor J and Chah KF, 2018. Prevalence and antifungal susceptibility of mycotic agents isolated from skin lesions of horses in Enugu State, Nigeria. Comparative Clinical Pathology 27: 589-595. https://doi.org/10.1007/s00580-017-2632-y 
Arne P and Deville M, 2010. Aspergillus fumigatus in poultry. International Journal of Microbiology 14: 115-210. https://doi.org/10.1155/2011/746356

Babayemi OJ, Abu OA and Opakunbi A, 2014. Integrated animal husbandry for schools and colleges, Ist Ed. Positive Press Ibadan, Nigeria, pp: 20-122.

Bancroft JD and Gamble M, 2008. Theory and Practice of Histological Techniques, 6th Ed; Churchill Livingstone Elsevier: Philadelphia, PA, USA.

Baron EJ, Murray PR, Jorgensen JH, Pfaller MA and Yolken RH, 2003. Manual of Clinical Microbiology, 8th Ed. SM press, Washington

Bonifaz A and Tirado-Sánchez A, 2017. Cutaneous disseminated and extra cutaneous sporotrichosis: current status of a complex disease. Journal of Fungi 2017: 3-6. https://doi.org/10.3390/jof3010006

Bauer AW, Kirby WMM, Sherris JC and Turck M, 1966. Antibiotic susceptibility testing by a standardized single disk method. American Journal of Clinical Pathology 45: 493-496. https://doi.org/10.1093/ajcp/45.4_ts.493

Cecil JA and Wenzel RP, 2009. Voriconazole: a broad-spectrum triazole for the treatment of invasive fungal infections. Expert Review of Hematology 3: 237-254. https://doi.org/ 10.1586/ehm.09.13

Chan GF, Sivaranjini S, Idris TN, Puad SA and Rahman AZ, 2013. Multiple rare opportunistic and pathogenic fungi in persistents foot skin infection. Pakistan Journal of Biological Science 16: 208-218. https://doi.org/10.3923/ pjbs.2013.208.218

Chihaya Y, Furusawa Y, Okada H, Matsukawa K and Matsui Y, 1991. Pathological studies on systemic mycoses in calves. Journal of Veterinary Medical Science 53: 1051-1058. https://doi.org/10.1292/jvms.53.1051

Dahl MV, 1994. Dermatophytosis and the immune response. Journal of the American Academy of Dermatology 31: S3441. https://doi.org/10.1016/s0190-9622(08)81265-0

Dobesova O, Schwarz B, Velde K, Jahn P, Zert Z and Bezdekova B, 2012. Guttural pouch mycosisin horses: a retrospective study of 28 cases. Veterinary Research 171: 561. https://doi.org/10.1136/vr.100700

Ellis D, Stephen D, Helen A, Rosemary H and Robyn B, 2000. Descriptions of Medical Fungi, 2nd Ed. Mycology Unit, Women's And Children's Hospital School Of Molecular \& Biomedical Science University Of Adelaide, Australia.

Elora GD, Amy RB, Sawyer M, Alex WC, Alix A, Jason ES and Deborah AH, 2018. Evolution of drug resistance in an antifungal-naive chronic Candida lusitaniae infection. PNAS 115: 12040-12045. https://doi.org/10.1073/pnas. $\underline{1807698115}$

Emily O, Obaghwarhievwo AJ and Osagie OM, 2020. Antioxidant activities of aqueous bitter kola (Garcinia Kola) seed extract on Wistar rats. Journal of Medicine: Study and Research 3: 013. https://doi.org/10.24966/MSR$\underline{5657 / 100013}$

Ezeifeka GO, Orji MU, Mbata T and Patrick AO, 2003. Antimicrobial Activities of Cajanus cajan, Garcinia kola and Xylopia aethiopica on pathogenic microorganisms. Biotechnology 3: 41-43. https://doi.org/10.3923/biotech. 2004.41.4

Herbrecht R, Denning DW, Patterson TF, Bennett JE, Greene RE, Oestman JW, Kern WV, Marr KA, Ribaud P, Lortholary O, Sylvester R, Rubin RH, Wingard JR, Stark P, Durand C, Caillot D, Thiel E, Chandrasekar PH, Hodges MR, Schlamm HT, Troke PF and de Pauw B, 2002. Voriconazole versus amphotericin B for primary therapy of invasive aspergillosis. New England Journal of Medicine 347: 408-415. https://doi.org/10.1056/NEJMoa020191

Feifei G, Weiping H, Shuzhen X, Su Wa, Xinxin L, Qian Z, Yuxing N and Lizhong H, 2020. Antimicrobial Resistance and Molecular Epidemiology of Staphylococcus aureus
Causing Bloodstream Infections at Ruijin Hospital in Shanghai from 2013 to 2018. Scientific Reports 10: 6019. https://doi.org/10.1038/s41598-020-63248-5

Ibedu CL, Ihetu CC, Okoro OS and Obeagu EI, 2018. Phytochemical composition and antimicrobial properties of Garcinia kola (Bitter Kola) seed extract. International Journal of Current Research in Chemistry and Pharmaceutical Sciences 5: 8-12. https://doi.org/10.22192/ ijcrcps.2018.05.11.002

Icheku V, Onianwah IF and Nwulia A, 2018. A descriptive crosssectional study on various uses and outcomes of Garcinia kola among people of Oshimili North in the Delta State of Nigeria. International Quarterly Journal of Research in Ayurveda 39: 132-138. http://doi.org/10.4103/ayu. AYU19516

Imran M, Cao S, Wan SF, Chen Z, Saleemi MK, Wang N, Naseem $\mathrm{MN}$ and Munawar J, 2020. Mycotoxins - a global one health concern: A review. Agrobiological Records 2: 1-16. https://doi.org/10.47278/journal.abr/2020.008

Jensen HE, Olsen SN and Aalbaek B, 1994. Gastrointestinal aspergillosis and zygomycosis of cattle. Veterinary Pathology 31: 28-36. https://doi.org/10.1177/0300985894 03100104

Jensen HE, Aalbaek B, Basse A and Schanheyder H, 1992. The occurrence of fungi in bovine tissues in relation to portals of entry and environmental factors. Journal of Comparative Pathology 107: 127-140. https://doi.org/10.1016/00219975(92)90030-x

Jensen HE, Hau J, Aalbæk B and Schønheyder H, 1990. Indirect immunofluorescence staining and crossed immunoelectrophoresis for differentiation of Candida albicans and Geotrichum candidum. Mycoses 33: 519-526. https://doi.org/10.1111/myc.1990.33.11-12.519

Johnson LB and Kauffman CA, 2003. Voriconazole: a new triazole antifungal agent. Clinical Infectious Disease 36: 630-637. https://doi.org/10.1086/367933

Karp NA, Meehan TF, Morgan H, Mason JC, Blake A, Kurbatova N, Smedley D, Jacobsen J, Mott RF, Iyer V, Matthews P, Melvin DG, Wells S, Flenniken AM, Masuya H, Wakana S, White JK, Lloyd KCK, Reynolds CL, Paylor R, West DB, Svenson KL, Chesler EJ, de Angelis MH, TocchiniValentini GP, Sorg T, Herault Y, Parkinson H, Mallon AM and Brown SDM, 2015. Applying the ARRIVE guidelines to an in vivo database. PLoS Biology 13: e1002151. https://doi.org/10.1371/journal.pbio.1002151

Kubkomawa HI, 2017. Indigenous Breeds of Cattle, their Productivity, Economic and Cultural Values in SubSaharan Africa: A Review. International Journal of Research Studies in Agricultural Sciences 3: 27-43. http://doi.org/10.20431/2454-6224.0301004

Mamun M, Hassan J, Nazir K, Islam A, Zesmin K, Rahman B and Rahman T, 2017. Prevalence and molecular detection of quinolone-resistant E. coli in rectal swab of apparently healthy cattle in Bangladesh. International Journal of Tropical Diseases and Health 24: 1-7. https://doi.org/ 10.9734/IJTDH/2017/34404

Marimon R, Cano J, Gené J, Sutton DA, Kawasaki M and Guarro J, 2007. Sporothrix brasiliensis, S. globosa, and S. mexicana, Three New Sporothrix Species of Clinical Interest. Journal of Clinical Microbiology 45: 3198-3206. https://doi.org/ 10.1128/JCM.00808-07

McEwen SA and Fedorka-Cray PJ, 2002. Antimicrobial use and resistance in animals. Clinical Infectious Diseases 34: S93S106. https://doi.org/10.1086/340246

McFarland J, 1907. Nephelometer: an instrument for media used for estimating the number of bacteria in suspensions used for calculating the opsonic index and for vaccines. Journal of American Medical Association 14:1176-1178. https://doi.org/10.1001/jama.1907.25320140022001f 
Okoli UJ, 1991. An Investigation into the hypoglycemic activity of GB1 biflavonoids of Garcinia kola. B. Pharma Undergraduate Project, University of Nigeria, Nsukka, Nigeria. pp: 15-20.

Oluyemi KA, Omotuyi IO, Jimoh OR, Adesanya OA, Saalu CL and Josiah SJ, 2007. "Erythropoietic and anti-obesity effects of Garcinia cambogia (bitter kola) in Wistar rats. Biotechnology and Applied Biochemistry 46: 69-72. https://doi.org/10.1042/BA20060105

Ovharhe OJ, Okpara O and Asedegbega C, 2020. Assessment of stakeholders' contributions to livestock development in Delta State, Nigeria: Rural infrastructure intervention. Open Agriculture 5: 656-668. https://doi.org/10.1515/opag2020-0067

Panciera RJ and Confer AW, 2010. Pathogenesis and pathology of bovine pneumonia. Veterinary Clinics of North America: Food Animal Practice 26: 191-214. https://doi.org/10.1016 /j.cvfa.2010.04.001

Paphitou NI, 2013. Antimicrobial resistance: action to combat the rising microbial challenges. International Journal of Antimicrobial Agents 42: 25-28. https://doi.org/10.1016/ j.ijantimicag.2013.04.007

Patel G, Simon D, Scheetz MH, Crank CW, Lodise T and Patel $\mathrm{N}, 2009$. The effect of time to antifungal therapy on mortality in candidemia associated septic shock. American Journal of Therapeutics 16: 508-511. https://doi.org/ 10.1097/MJT.0b013e3181a1afb7

Penduka D, Okoh OO and Okoh AI, 2011. In-vitro antagonistic characteristics of crude aqueous and methanolic extracts of Garcinia kola (Heckel) seeds against some vibrio bacteria. Molecules 16: 2754-2765. https://doi.org/10.3390/ molecules 16042754

Pfaller MA, Jones RN, Doern GV, Sader HS, Messer SA and Houston A, 2000. Bloodstream infections due to Candida species: SENTRY Antimicrobial Surveillance Program in North America and Latin America, 1997-1998. Antimicrobial Agents Chemotherapy 44:747-751. https://doi.org/10.1128/aac.44.3.747-751.2000

Pier AC, Smith JMB, Alexiou H, Ellis DH, Lund A and Pritchard RC, 1994. Animal ringworm - its aetiology, public health significance and control. Journal of Medical and Veterinary Mycology 32: 133-150. https://doi.org/10.1080/02681219 480000791

Pieter PL, Robbert GB, Alexander FADS, Steven S, Walter JFMV, Ed JK, Judith P, Ben H, Henrich AL, Willem JGM, Anton FH, Hans LH, Bart JAR, Martha TB and Paul EV, 2019. Voriconazole Resistance and Mortality in Invasive Aspergillosis: A Multicenter Retrospective Cohort Study. Clinical Infectious Diseases 68: 1463-1471. https://doi.org/ $10.1093 / \mathrm{cid} / \mathrm{ciy} 859$

Puntenney SB, Wang Y and Forsberg NE, 2003. eds. Mycotic infections in livestock: Recent insights and studies on etiology, diagnostics and prevention of Hemorrhagic Bowel Syndrome. Southwest Nutrition \& Management Conference; 2003. Pheonix, Tuscon: University of Arizona, Department of Animal Science, pp: 49-63.

Ramírez-Romero R, Nevárez-Garza AM, Rodríguez-Tovar LE, Wong-González A, Ledezma-Torres RA and Hernández-
Vidal G, 2012. Histopathological analogies in chronic pulmonary lesions between cattle and humans: Basis for an alternative animal model. Scientific World Journal 2012: 647403. https://doi.org/10.1100/2012/647403

Rodrigues AM, de Hoog GS, Zhang Y and Camargo ZP, 2014. Emerging sporotrichosis is driven by clonal and recombinant Sporothrix species. Emerging Microbes and Infections 3: e32-10. https://doi.org/10.1038/emi.2014.33

Rosowski EE, Jiaye H, Jan H, Keller NP and Anna H, 2020. Efficacy of Voriconazole against Aspergillus fumigatus Infection Depends on Host Immune Function. Antimicrobial Agents Chemotherapy 64: e00917-19. https://doi.org/10.1128/AAC.00917-19

Sanglard D, 2011. Resistance to antifungal drugs: In: Essentials of Clinical Mycology, 2nd Ed. Kauffman CA, Pappas PG, Sobel JD and William E. Dismukes WE (eds). Springer Science+Business Media, New York, USA, pp: 135-151.

Seanego CT and Ndip RN, 2012. Identification and antibacterial evaluation of bioactive compounds from Garcinia kola (Heckel) seeds. Molecules 17: 6569-6584. https://doi.org/10.3390/molecules17066569

Schlecht LM, Peters BM, Krom BP, Freiberg JA, Hansch GM, Filler SG, Jabra-Rizk MA and Shirtliff ME, 2015. Systemic Staphylococcus aureus infection mediated by Candida albicans hyphal invasion of mucosal tissue. Microbiology 161:168-181. https://doi.org/10.1099/mic.0.083485-0

Seifi S, Shokri $\mathrm{H}$ and Madab MK, 2018. Isolation and characterization of mycoflora of chicken hatcheries in Mazandaran province, North of Iran. Veterinary Research Forum 9: 373-378. https://doi.org/10.30466/vrf. 2018.33106

Sephavard A, Abdi J, Shirkhani Y and Soleimannejad S, 2009. Dermatophytosis in western part of Iran, Khorramabad. Asian Journal of Biological Science 2: 58-65. https://doi.org/10.3923/ajbs.2009.58.65

Seyedmousavi S, Bosco SMG, de Hoog S, Ebel F, Elad D, Gomes RR, Jacobsen ID, Jensen HE, Martel A, Mignon B, Pasmans F, Piecková E, Rodrigues AM, Singh K, Vicente VA, Wibbelt G, Wiederhold NP and Guillot J, 2018. Fungal infections in animals: a patchwork of different situations. Medical Mycology 56: 165-S187. https://doi.org/10.1093/ mmy/myx104

Thornton PK, 2010. Livestock production: recent trends, future prospects. Transactions of the Royal Society B 365: 2853 2867. https://doi.org/10.1098/rstb.2010.0134

Thornton PK, Jones PG, Owiyo T, Kruska RL, Herrero M, Kristjanson P, Notenbaert A, Bekele N, Omolo A, Orindi V, Ochieng A, Otiende B, Bhadwal K, Anatram S, Kumar V and Kelkar U, 2006. Mapping climate vulnerability and poverty in Africa. Report to the Department for International Development. ILRI, Nairobi, Kenya. www.dfid.gov.uk/research/mappingclimate.pdf. Accessed 20-12-20.

Yesuf M, Mazengia M and Mersha C, 2012. histopathological and bacterial examination of pneumonic lungs of small ruminants slaughtered at Gondar, Ethiopia. AmericanEurasian Journal of Scientific Research 7: 226-231. https://doi.org/ 10.5829/idosi.aejsr.2012.7.6.66140 